\title{
Incomplete trimorphic incompatibility expression in Oxalis compacta Gill. ex Hook. et Arn. subsp. compacta in the central Chilean Andes
}

\section{Expresión incompleta de incompatibilidad trimórfica en Oxalis compacta Gill. ex Hook. et Arn. subsp. compacta en los Andes de Chile central}

\author{
Mary T. K. Arroyo ${ }^{1 *}$, Ana María Humaña ${ }^{1}$, Daniela Domínguez ${ }^{1} \&$ Gus Jespersen $^{2}$ \\ ${ }^{1}$ Institute of Ecology and Biodiversity (IEB) and Departamento de Ciencias Ecológicas, Facultad de Ciencias, Universidad de \\ Chile, Casilla 653, Santiago, Chile. \\ ${ }^{2}$ School of Forest Resources, College of the Environment, University of Washington, Seattle, USA. \\ *southern@uchile.cl
}

\begin{abstract}
The expression of trimorphic incompatibility was investigated in a high altitude population of Oxalis compacta subsp. compacta distributed in the upper alpine belt $(3100-3470 \mathrm{~m})$ of the central Chile Andes. Stigma-anther reciprocity $(2$ populations), morph representation (7 populations), unassisted selfing capacity and open-pollination fruit set (6 populations) were determined. O. compacta ssp. compacta es highly dependent on external pollinators. Although it has typical tristylous flowers, considerable seed set is possible following illegitimate intermorph and intramorph cross pollination. Open pollination fruit set varied from $9-83 \%$ and on average was lower in the higher-elevation populations. The possibility of seed set following two kinds of illegitimate cross pollination is seen as a means of enhancing reproductive output by enabling more effective use of the limited pollinator resource in the high alpine environment, where fruit set shows high inter-annual variability and there is some evidence for pollination limitation in Oxalis compacta subsp. compacta.
\end{abstract}

KEYwORDs: Oxalis compacta subsp. compacta, trimorphic incompatibility relationships, high alpine, central Chilean Andes.

\section{RESUMEN}

Se investigó la expresión de incompatibilidad trimórfica en una población de Oxalis compacta subsp. compacta distribuida en la zona alpina superior de los Andes de Chile central. Se determinó la reciprocidad de los estigmas y anteras (dos poblaciones), representación de morfos florales (7 poblaciones), capacidad para autofecundación no asistida y polinización abierta (6 poblaciones). O. compacta subsp. compacta es altamente dependiente de polinizadores externos. No obstante la presencia de flores tristilicas, las dos categorías ilegítimas de polinización dieron semillas. La producción de frutos mediante polinización abierta fluctuó entre $9-83 \%$ y en promedio fue menor en las poblaciones de mayor elevación. Se plantea que la capacidad de formar semillas mediante polinización ilegítima permitirá el uso más eficaz del recurso limitado de polinización en la zona andina superior, donde los niveles de fructificación varían entre años y existe evidencia preliminar de limitación de polen en Oxalis compacta subsp. compacta.

Palabras clave: Oxalis compacta subsp. compacta, relaciones de incompatibilidad trimórfica, alpino superior, Andes de Chile central.

\section{INTRODUCTION}

The tristylous breeding system has now been confidently reported in 28 families of flowering plants (Barrett \& Shore 2008). Typical tristylous species have three floral morphs, characterized by reciprocal positioning of the stamens and style (Barrett 1992, Barrett et al. 2000) (Fig. 1). The three floral morphs are generally found in equal proportions in populations, a condition known as isoplethy. The floral organs occur at three distinct levels. In each floral morph, the stamens occur at two levels, while stigmas occur at a third (Fig. 1). The three floral morphs (Long-style, hereafter L-style; Mid-style, hereafter M-style; Short-style, hereafter S-style) are normally incapable of producing seed following self-fertilization, and thus are strongly dependent on pollinators. Additionally, in contrast with typical homomorphic incompatibility, not all cross pollination combinations in a population result in seed set. Compatible pollinations are those occurring between anthers and stigmas located at the same level in the flower (Fig. 1). Darwin 
(1877) referred to these types of pollinations as legitimate cross-pollinations. In total there are six possible legitimate pollinations (e.g. L x 1S, L x 1M; Fig. 1). Illegitimate crosspollination combinations that fail to result in seed are those involving an anther level that is different from that of the style length ( $\mathrm{L} \times \mathrm{mS}, \mathrm{L} \times \mathrm{sM}$, etc.).

Tristyly and variants thereof, has been reported in many species of Oxalis (e.g. Ornduff 1964, 1972, Weller 1976, 1980, Marco \& Arroyo 1998, Pacques de Barro Pacheco \& Coleman 1989, Luo et al. 2006, Castro et al. 2007, Weller et al. 2007, Abid 2010). However, in many species of Oxalis with tristylous flowers it is unknown whether the tristylous floral polymorphism is underpinned by strong heteromorphic incompatibility as has been experimentally verified in a number of Oxalis species (e.g. Fyfe 1950, Weller 1976, 1980, Marco \& Arroyo 1998, Zietsman et al. 2008).

In this paper we focus on the breeding system and openpollination seed set in Oxalis compacta subsp. compacta, one of the highest-growing plants in the Andes of central Chile. In the central Chilean Andes, O. compacta subsp. compacta is morphologically tristylous. Based on data for one summer season, Domínguez (2010) reported consistently lower flower visitation rates at the upper extreme of $O$. compacta's altitudinal distribution. This situation could be expected to lead to alterations in the tristylous breeding system in the direction of self-pollinating ability and/or the ability to produce seeds in some of the illegitimate cross combinations found in a typical tristylous species.

At high altitudes, cold and unpredictable weather conditions and strong microclimatic differences related to slope-aspect and substrate type can have huge effects on flower visitation rates, local pollinator composition and consequently, reproductive success (Totland 1994, Bergman et al. 1996, Rozzi et al. 1997, Torres-Díaz et al. 2007). In accordance with these conditions, major community studies in the South American Andes $\left(18^{\circ} \mathrm{S}\right.$, $33^{\circ} \mathrm{S}$ and $50^{\circ} \mathrm{S}$ ) have revealed an overall altitudinal decline in flower visitation rates above the tree line to the extent of a $50 \%$ decrease in pollinator availability between the two altitudinal extremes of the alpine belt (Arroyo et al. 1985, Arroyo \& Squeo 1990). Pollen limitation, moreover, has been reported in many alpine species (García-Camacho \& Totland 2009), including for one in the lower alpine on our study sites (Muñoz \& Arroyo 2006). This general scenario fits the autogamous fertility insurance hypothesis where low or unreliable pollination service is seen to favor selfcompatibility coupled with capacity for unassisted selfpollination (Kalisz \& Vogler 2003). However, even though it is known that average flower visitation rates descend with elevation in the central Chilean Andes, it cannot be a priorily assumed that all high elevation species are inefficiently pollinated. Arroyo et al. $(1985,2006)$ proposed that alpine species may acquire compensatory traits (such as increased flower longevity) which increase the probability that a flower is pollinated when pollination service is depressed or temporally and spatially fluctuating, thereby enabling the maintenance of outcrossing breeding systems and high seed set levels (increased pollination probability hypothesis). Given the above possibilities, it is relevant to ask if tristylous Oxalis compacta ssp. compacta shows heteromorphic incompatibility and investigate levels of fruit and seed set at different elevations.

For Oxalis compacta subsp. compacta we determined: a) seed set following all combinations of self-pollination, legitimate cross-pollination, illegitimate intermorph cross pollination and illegitimate intramorph cross-pollination; b) style morph frequencies in populations; c) capacity for autonomous self-pollination fruitset, and, d) open-pollination fruit set. We also (e) verified the reciprocal positions of the styles and the stamens in a sample of populations.

\section{MATERIALS AND METHODS}

STUDY SPECIES AND STUDY SITES

Oxalis is a large and widespread plant genus (Hussey et al. 1997) that is well represented in the high Andes of South America (Arroyo et al. 2010). O. compacta Gill. ex Hook. et Arn. subsp. compacta (Fig. 2) and a second mostly subalpine taxon (O. compacta Hook. et Arn. subsp. berteroana (Barnéoud) Lourteig) belong to the non-bulbous section Alpinae which comprises 25 species occurring in the Andes from Ecuador to the extreme south of South America (Lourteig 2000). O. compacta subsp. compacta (hereafter $O$. compacta) is a perennial herb mostly distributed in the upper alpine belt in the Andes of central Chile (IV of Coquimbo - VIII of Bío-Bío Regions) and Argentina (La Rioja to Santa Cruz Province) (Lourteig 2000). In its northern distribution area it grows to 4350 m.a.s.1. Southward in the central Chilean Andes, where the upper limit for consistent vascular plant vegetation descends to around 3700-3800 m.a.s.1., $O$. compacta is commonly found to around 3500 m.a.s.l. with occasional plants growing as high as 3600 m.a.s.l.

Oxalis compacta produces an attractive crop of yellow flowers (petals ca. 4 -10 mm long) borne in reduced 1-flower cymes (Fig. 2). The main pollinators in the central Chilean Andes are high Andean butterflies (especially Yramea modesta, Phulia nymphula) and tiny bees of the genus Liphanthus (Andrenidae) (Arroyo et al. 1982, Domínguez 2010).

Our work was carried out in seven large populations, representative of the lower (denoted by -low) and upper (high) parts of the altitudinal range of $O$. compacta, located in three high altitude areas (La Parva (LP), Valle Nevado (VN), Piedra Numerada (PN)) in the central Chilean Andes $\left(33^{\circ} \mathrm{S}\right)$ These areas are found in an overall area of around $15.3 \mathrm{~km}^{2}$ (see also Table II for altitudinal details of all populations). The detailed crosses were carried out in one of the highest 
populations of $O$. compacta early in the flowering season in the austral summer of 2008-2009. Stigma-anther reciprocity was determined in two populations from material collected in $70 \%$ during the early to late flowering season (20082009 and 2010-2011 summers); morph representation was determined in 7 populations at the peak of the flowering season over the 2007-2008 and 2008-2009 austral summer. Unassisted selfing capacity and open-pollination fruit set were determined in 6 populations during the 2009-2010 austral summer.

STIGMA-ANTHER HEIGHTS AND STYLE MORPH REPRESENTATION In order to quantify stigma-anther reciprocity, stigma and anther heights were measured from the base of the ovary (under a dissecting microscope) in flowers preserved in $70 \%$ alcohol for PN-low and VN-high, representing the two altitudinal extremes of the distribution of $O$. compacta on our study sites. The 50 flowers of the L-, M- and S-morph, respectively, came from a total of 80 (VN-high) and 150 (PN-low) plants. Stigma-anther height reciprocity was assessed using the Relative Reciprocity Index, $\mathrm{R}=(\mathrm{E}-$ S)/(E+S), (Richards \& Koptur 1993), where E is anther height and $\mathrm{S}$ is stigma height in the morph compared at the corresponding level. In a tristylous species two values of this index must be calculated for each style morph. $\mathrm{R}$ varies between 1 and -1 , with 0 indicating perfect reciprocity. The seven populations of $O$. compacta assessed for style morph frequency represent the two altitudinal extremes of the distribution. Style morph counts were made at the height of the flowering season by directly surveying all or a large number of plants in the field or by determining the style morph of a single $70 \%$ alcohol-preserved flower per plant in the laboratory.

\section{TRISTYLOUS INCOMPATIBILITY RELATIONSHIPS}

We investigated the tristylous incompatibility relationships of $O$. compacta in the VN-high population located at 3450 m.a.s.l. Large plants containing abundant buds so as to insure application of all treatments described below on each plant, were fully isolated from pollinator activity in tent-like exclosures in which transparent muslin fabric was mounted on light metal frames. We performed legitimate intermorph (two types on each stylar morph), illegitimate intermorph (two types on each stylar morph) and illegitimate intramorph (two types on each stylar morph) cross pollinations. Each pollination treatment and the emasculation treatment was carried out on one flower per plant, replicated across 10 L-morph, $10 \mathrm{M}$-morph and seven S-morph plants, to give an initial total number of 27 experimental plants and 270 experimental flowers.

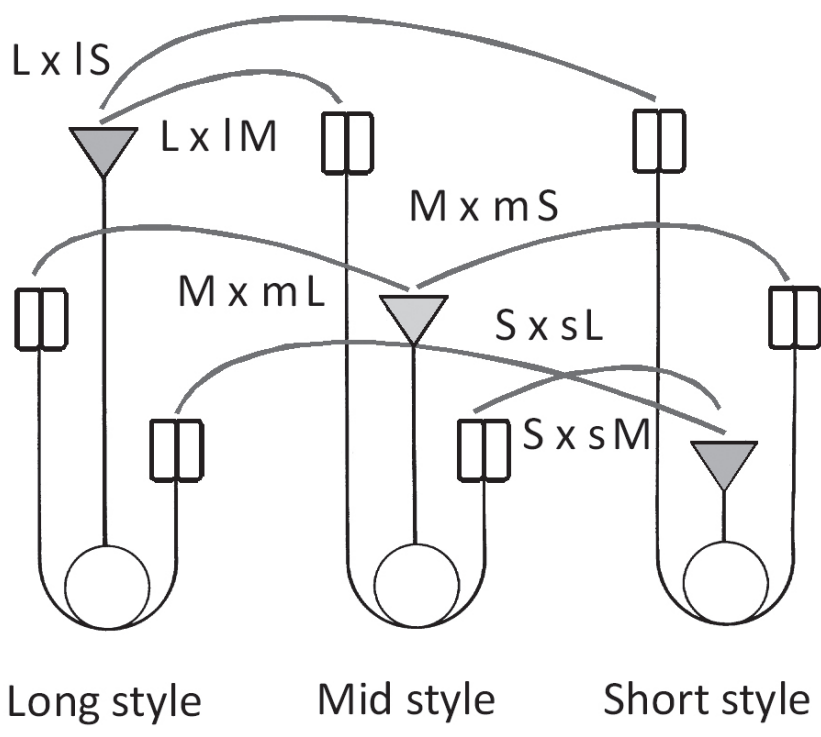

FigURE 1. Simplified diagram showing the only crosses (legitimate intermorph crosses) leading to ovule fertilization in a tristylous species with hetermorphic incompatibility (after Weller et al. 2007). The first upper case letter of the cross indicates the ovulate parent. The second upper case letter indicates the pollen donor parent. The lower case letter indicates the anther level from which the pollen was obtained. All other cross combinations between different anther and stigma heights are illegitimate and do not produce fertilized ovules. Additionally, self-fertilization on the three stylar morphs is not possible.

Figura 1. Esquema simple que muestra los únicos cruces (cruces legítimos entre morfos) que conllevan a la fecundación de óvulos en una especie tristílica con incompatibilidad heteromórfica (modificado de Weller et al. 2007). La primera letra en mayúscula señala la planta ovulada. La segunda letra en mayúscula es la planta dadora del polen. La letra en minúscula señala la altura de las anteras de las cuales proviene el polen de la planta dador del polen. Todas las combinaciones entre anteras y estigmas de diferentes alturas en las flores son ilegítimas y no producen óvulos fecundados. Además los tres morfos estilares no son capaces de autofecundarse. 


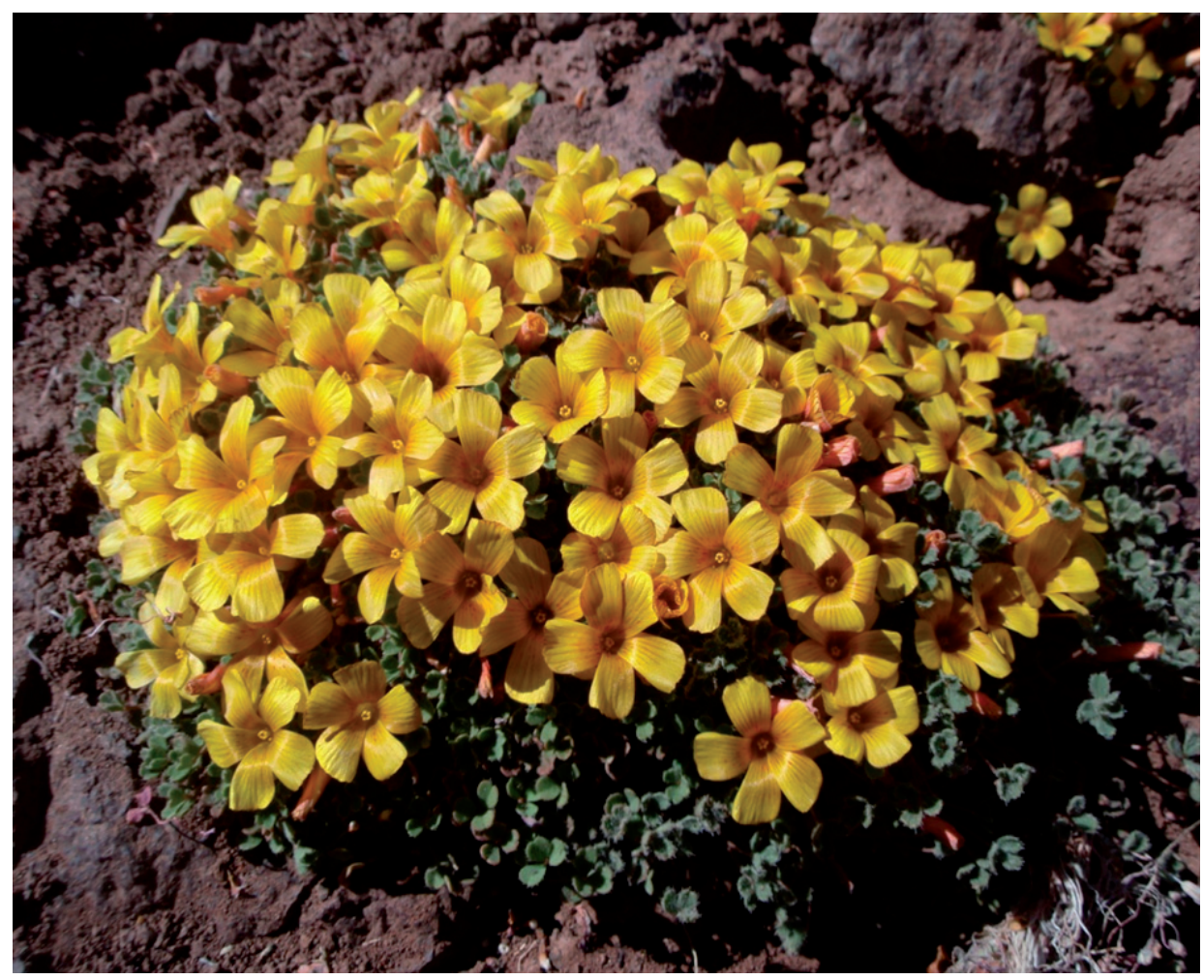

FIGURE 2. Oxalis compacta subsp. compacta, PN-high, 3470 m.a.s.1.

FIGURA 2. Oxalis compacta subsp. compacta, PN-high, 3470 m.s.m.

TABLE I. The Richards \& Koptur (1993) Reciprocity index (R) for Oxalis compacta subsp. compacta populations in the central Chilean Andes. The values for a particular morph correspond to its two anther whorls compared with the corresponding style height in the other two style morphs, respectively.

TABLA I. Índice de Reciprocidad de Richards \& Koptur (1993) para poblaciones de Oxalis compacta subsp. compacta en los Andes de Chile central. Los valores para un morfo determinado corresponden a sus dos niveles de anteras, comparados con el mismo nivel del estigma de los otros dos morfos, respectivamente.

\begin{tabular}{lccc}
\hline & \multicolumn{3}{c}{ Organ LEVEL } \\
\cline { 2 - 4 } Morph & ShorT & Mid & LONG \\
\hline $\begin{array}{l}\text { PN-low } \\
\text { Long style }\end{array}$ & 0.01 & 0.03 & - \\
Mid style & 0.02 & - & 0.01 \\
Short style & - & 0.05 & 0.03 \\
& & & \\
$V N$-high & & & \\
Long style & -0.03 & 0.04 & \\
Mid style & 0 & & 0.01 \\
Short style & - & 0.00 & 0.06 \\
\hline
\end{tabular}



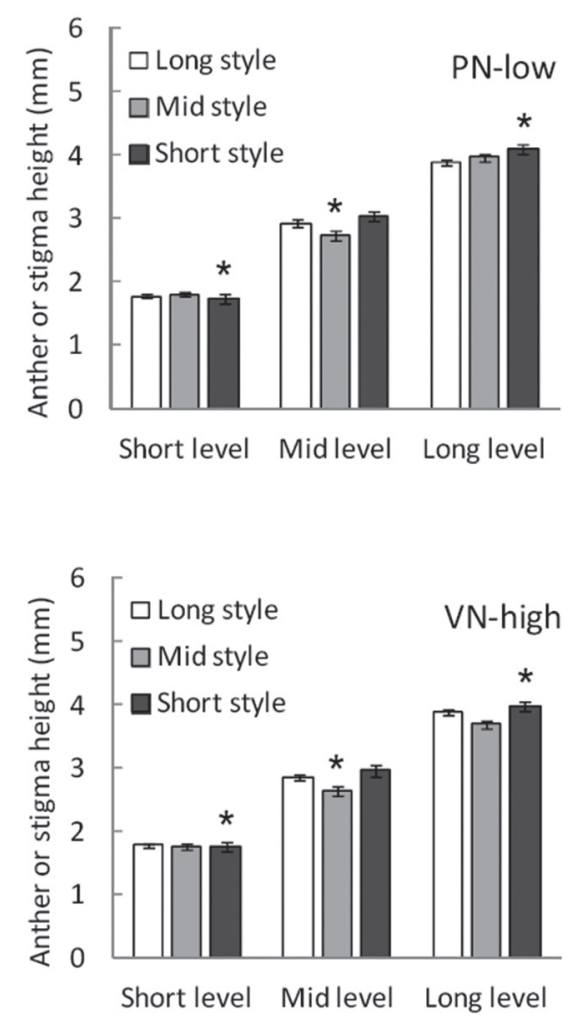

Figure 3. Anther and stigma heights in the three style morphs of Oxalis compacta subsp. compacta, PN-low and VN-high populations. ${ }^{*}$ indicates style height.

Figura 3. Alturas de los anteras y estigmas de los tres morfos estilares en Oxalis compacta subsp. compacta, poblaciones PNlow y VN-high. * indica la altura del estigma.

The two legitimate intermorph crosses on each of the three morphs were made with pollen from the anther height corresponding to the stigma height of the recipient plant, but coming from the other two morphs, respectively. The two illegitimate intermorph crosses made on each of the three morphs involved pollen of the anther height not corresponding to the style height of the recipient plant, coming from the other two morphs, respectively. The two illegitimate intramorph cross-pollinations made on each of the three morphs considered two different plants of the same morph, using one of the anthers levels each time, respectively. Additionally we performed hand selfpollinations (two types on each stylar morph using only one of the recipient plant anther levels at a time) and unassisted selfing trials (one type per stylar morph). In order to discard those types of agamospermy that do not require pollen transfer, we also performed emasculations (one type per stylar morph, eliminating both anther levels simultaneously). The complete array of specific pollination treatments implemented, arranged according to major category, can be found in Figure 4.
Prior to the crosses, anthers of both whorls on the recipient plant were emasculated. However, well into the crossing program, we abandoned emasculation of the shortanther level because of the difficulty of manipulating at the base of the small flower. Deposition of pollen from this anther level on the stigmas of the same flower (either in the M-morph or L-morph) is unlikely. For cross-pollination, pollen was collected from several different individuals of the relevant style morph and anther level.

The experimental flowers were monitored for fruit set and the fruits collected around two-three weeks following pollination. Following Weller et al. (2007), mean number of normal seeds obtained per flower was employed to compare the performance of the individual cross and self-pollination treatments. The alternative of comparing mean seed number per ovule per flower crossed was not possible as ovule number in this species of Oxalis cannot be reliably registered at the fruiting stage. Ovule number in VN-high (mean $\pm 2 \mathrm{SE}$ for ovule number; $11.4 \pm 0.72$ (L-Morph), $11.0 \pm 0.53$ (Mmorph); $10.7 \pm 0.42$ (S-Morph) based on a sample of flowers drawn for 50 plants per morph is not significantly different $\left(\mathrm{H}_{2,150}=2.12 ; \mathrm{p}=0.33\right)$, justifying direct comparison of seed per flower pollinated to detect incompatibility relationships.

UNASSISTED SELF-POLLINATION AND OPEN-POLLINATION FRUIT SET Unassisted self-pollination fruit set levels were assessed in six populations in order to determine the degree of pollinator dependence in $O$. compacta over a larger geographical area and altitudinal range than represented by the $\mathrm{VN}$-high population. For these same populations we determined open-pollination fruit set. The six populations comprised one high- and one low-elevation population in each of the three high altitude areas (LP, VN, PN). Both pollination types were assessed over the austral summers of 20082009 (hereafter Year-1) and 2009-2010 (hereafter Year-2) (2 populations x 3 areas x 2 years x 2 treatments) in an effort to capture inter-annual variation in fruit and seed set. For each pollination treatment several mature flower buds per plant were marked on two different sets of plants over the same dates in each population. In Year 1, for unassisted selfpollination, plant number varied from $15-18$ per population and flower number monitored from 42 to 71 per population; for open-population the samples sizes were 17-18 plants per population and 52-67 flowers per population. In Year2 , for unassisted self-pollination plant number was 25 per population and flower number monitored from 77 to 124 per population; for open-population the samples sizes were 2425 plants per population and 83-123 flowers per population. Open-pollination plants remained exposed to pollinators, while those observed for unassisted self-pollination were individually isolated in small exclosures (ca. $15 \mathrm{~cm}$ diameter) consisting of a basal plastic rim ( $1.5 \mathrm{~cm}$ wide) forced into the ground, upon which a pollination bag was mounted. All fruits were harvested around two weeks later. 


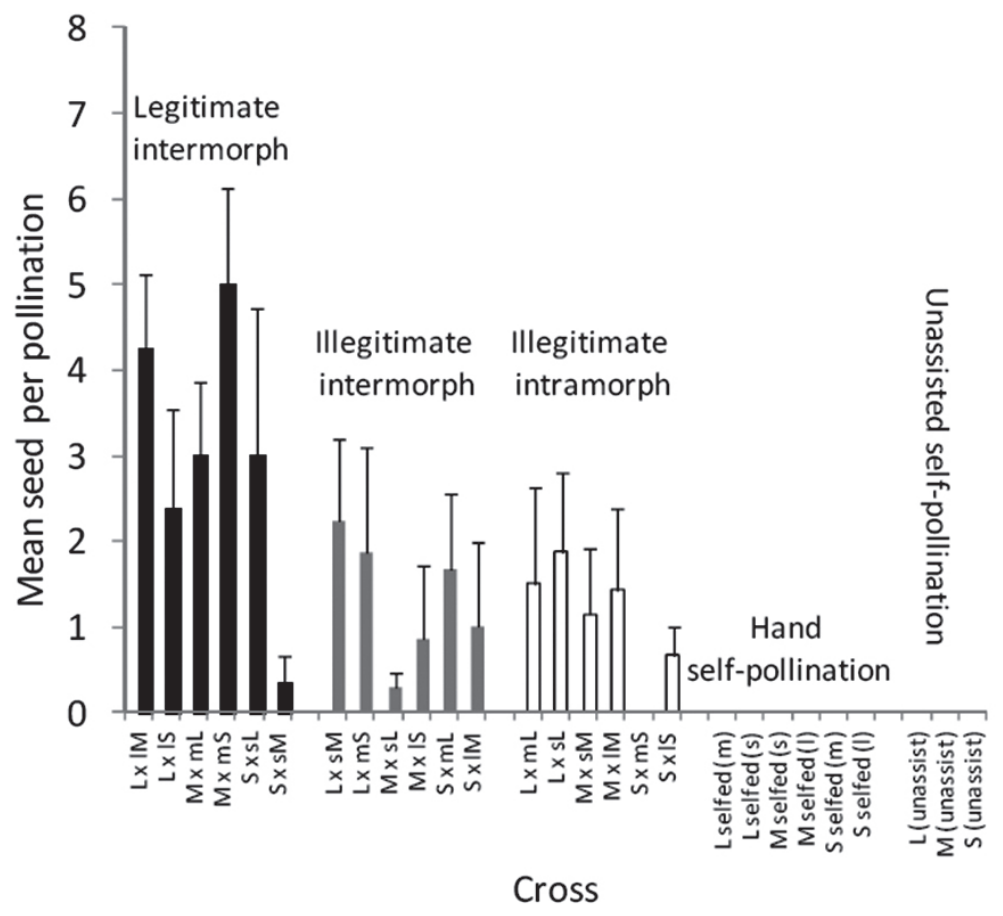

FIGURE 4. Mean $( \pm 1 \mathrm{SE})$ seed per flower crossed according to major cross category and specific cross-type in tristylous Oxalis compacta subsp. compacta, 3450 m.a.s.l. (VN-high), Andes of central Chile. Notation follows Weller et al. (2007) as per Figure 1. The first upper case letter of the cross indicates the ovulate parent. The second upper case letter indicates the pollen donor parent. The lower case letter indicates the anther level from which the pollen was obtained. Bars are 1SE. No seed set is expected in the two illegitimate cross categories in a typical tristylous incompatibility system.

Figura 4. Promedio ( \pm 1 ES) de semillas por flor cruzada según categoría mayor de cruzamiento y tipo específico de cruce en Oxalis compacta subsp. compacta, $3.450 \mathrm{~m}$ s.m, Andes de Chile central. La primera letra en mayúscula señala la planta ovulada. La segunda letra en mayúscula es la planta dadora del polen. La letra en minúscula señala la altura de las anteras de las cuales proviene el polen de la planta dadora del polen. No se esperan semillas en las dos categorías de cruzamientos ilegítimos en una especie tristílica que presenta la incompatibilidad heteromórfica. Ver texto para resultados de las pruebas estadísticas.

TABLE II. Proportions of the L-, M- and S-morph in populations of Oxalis compacta subsp. compacta within the upper alpine belt in the central Chilean Andes. + Data obtained in the 2007-2008 austral summer; all other populations studied over the 2008-2009 austral summer. PN-high and PN-high+ are different populations. A non significant G-value indicates isoplethy. * Significant G value.

TABLA II. Proporciones de los morfos L-, M- y B- en poblaciones de Oxalis compacta subsp. compacta en el piso andino superior en los Andes de Chile central. + Datos obtenidos en el verano austral de 2007-2008; las demás poblaciones fueron estudiadas en el verano de 20082009. PN-high y PN-high+ son poblaciones diferentes. Un valor no significativo de G indica la isopletia. * Valores significativos de G.

\begin{tabular}{|c|c|c|c|c|c|c|c|c|c|}
\hline Population & $\begin{array}{l}\text { AltitudE } \\
\text { (m.a.s.l) }\end{array}$ & $\begin{array}{l}\text { LATITUDE } \\
\left({ }^{\circ} \mathrm{S}\right)\end{array}$ & LONGITUDE $\left({ }^{\circ} \mathrm{W}\right)$ & $\mathrm{N}$ & LONG & MID & SHORT & G & $\begin{array}{l}\text { P-VALUE } \\
\text { (G-test) }\end{array}$ \\
\hline LP-low & 3100 & $33^{\circ} 19^{\prime} 50.84^{\prime \prime}$ & $70^{\circ} 16^{\prime} 17.66^{\prime \prime}$ & 838 & 0.35 & 0.34 & 0.32 & 0.98 & 0.61 \\
\hline VN-low & 3140 & $33^{\circ} 20^{\prime} 40.23^{\prime \prime}$ & $70^{\circ} 15^{\prime} 10.67^{\prime \prime}$ & 664 & 0.33 & 0.32 & 0.35 & 0.92 & 0.63 \\
\hline PN-low & 3110 & $33^{\circ} 20^{\prime} 04.40^{\prime \prime}$ & $70^{\circ} 14^{\prime} 38.94^{\prime \prime}$ & 766 & 0.38 & 0.31 & 0.31 & 7.74 & $0.0208 *$ \\
\hline LP-high & 3450 & $33^{\circ} 19^{\prime} 24.57^{\prime \prime}$ & $70^{\circ} 15^{\prime} 47.40^{\prime \prime}$ & 1883 & 0.34 & 0.31 & 0.35 & 4.87 & 0.09 \\
\hline VN-high & 3450 & $33^{\circ} 19^{\prime} 31.40^{\prime \prime}$ & $70^{\circ} 15^{\prime} 18.30^{\prime \prime}$ & 921 & 0.37 & 0.28 & 0.34 & 11.67 & $0.0029 *$ \\
\hline PN-high+ & 3420 & $33^{\circ} 19^{\prime} 70.14^{\prime \prime}$ & $70^{\circ} 14^{\prime} 18.69^{\prime \prime}$ & 614 & 0.35 & 0.25 & 0.40 & 21.92 & $0.00017^{*}$ \\
\hline$P N$-high & 3470 & $33^{\circ} 19^{\prime} 14.87^{\prime \prime}$ & $70^{\circ} 14^{\prime} 20.25^{\prime \prime}$ & 366 & 0.35 & 0.35 & 0.30 & 2.13 & 0.63 \\
\hline
\end{tabular}


StatisticAl TREATMENT

Style morph frequencies were tested for isoplethy using the $\mathrm{G}$ test. A non significant $\mathrm{G}$-value was taken to indicate isoplethy (Weller et al. 2007). Where the data were paired, we employed the Wilcoxon Matched Pairs tests to compare seed set per flower pollinated in the different pollination treatments given that the data could be paired. We employed non-parametric Analysis of Variance (ANOVA) (KruskalWallis Test) to look for potential differences in legitimate seed set per flower pollinated among floral morphs (nonpaired data) and the Mann-Whitney U Test (with Sequential Bonferroni correction) as an a posteriori test, given departures from normality (c.f. Zietsman et al. 2008). We employed the G-test to search for possible differences in the proportions of L-, M- and S-morph flowers setting fruit under open-pollination.

\section{RESULTS}

STIGMA-ANTHER HEIGHTS AND STYLE MORPH FREQUENCIES Strong reciprocal disposition of stigma and anther heights is evident in $O$. compacta (Fig. 3). R was consistently close to 0 (Table I), averaging 0.03 in PN-low and 0.01 in VN-high. All seven $O$. compacta populations surveyed contained the three style morphs of a typical tristylous species. Two high- and one low-elevation population were anisoplethic and characterized by a deficit in the M-morph, and in one case, also in the S-morph (Table II). In one of the remaining four populations (LP-high), there is a marginally significant tendency toward anisoplethy, again expressed as a deficit in the M-morph.

TRISTYLOUS INCOMPATIBILITY RELATIONSHIPS

Seed set failed for all treatments in nine of the 27 controlledpollination experimental plants (two L-morph, three M-morph and four S-morph plants). The 2008-2009 austral summer was dry and water stress acting through very early seed abortion may have affected the success of the crosses in the population where the controlled pollinations were undertaken. These plants were eliminated from the final analyses, reducing the number of experimental flowers to 180 .

Emasculated, non-pollinated plants failed to produce seed thus discarding those types of apomixis that do not require pollination. Details of results according to the main cross categories, stylar morph and specific anther height employed as a pollen source are given in Fig. 4. It can be seen that unassisted self-pollination and hand self-pollination failed in all three style morphs. These last results suggest that high alpine $O$. compacta is characterized by strong individual self-incompatibility and is highly dependent upon external pollinators.

Visual inspection of Fig. 4 shows that considerable amounts of seed were obtained in most of the individual illegitimate intermorph- and intramorph cross types, indicating imperfect expression of heteromorphic incompatibility in all three stylar morphs. The standard errors at the level of each specific cross (Fig. 4) are very large on account of the fact that a number of flowers in each specific cross type failed to produce seed, thus making any reliable statistical analysis at this very fine level problematical. In order to determine the overall level of imperfection of the Oxalis compacta heteromorphic incompatibility system we statistically analyzed the data at the level of treatment type (Table III, all morphs). In view of the total lack of seed following self-pollination, not surprisingly the three cross pollination treatments produced significant more seed than hand self-pollination (legitimate intermorph comparison: $\mathrm{z}=4.401, \mathrm{P}=1.077^{-05}$; illegitimate intermorph comparison: $\mathrm{z}=3.192, \mathrm{P}=0.001$; illegitimate intramorph comparison: $\mathrm{z}=3.07, \mathrm{P}=0.002$ ). Although seed set was produced in the two illegitimate cross-pollination treatments it was significantly lower than in the legitimate crosses (legitimate intermorph vs illegitimate intermorph: $\mathrm{z}=3.132, \mathrm{P}=0.002$; legitimate intermorph vs illegitimate intramorph: $\mathrm{z}=2.947, \mathrm{P}=0.003$ ). Seed production following the two illegitimate cross types was not significantly different $(\mathrm{z}=0.1143, \mathrm{P}=0.909)$.

These results indicate that while the tristylous breeding system of $O$. compacta deviates from a typical heteromorphic incompatibility system, the level of alteration fails to reach $100 \%$. In general, illegitimate pollination seed set can reach $40-41 \%$ the levels attained with under legitimate pollination, although, there is a trend for the percentage to be higher in the L- and S-morph, and lower in the M-morph (Table III). Finally we found no difference in the capacity of the three stylar morphs to contribute to the legitimate pollination seed pool (Kruskall-Wallis ANOVA: $\mathrm{H}_{(2.36)}=$ $2.49, \mathrm{P}=0.305)$.

UNASSISTED SELF-POLLINATION AND OPEN-POLLINATION FRUIT SET Over the observation period $5.0 \%$ (Year-1) to $5.4 \%$ (Year2) of the flowers in the unassisted self-pollination treatment became damaged before fruit set. In the case of the more exposed open-pollination treatment the corresponding losses were $10.9 \%$ (Year-2) to $18.5 \%$ (Year 1). Percent fruit set given in Figure 5 is based on the recuperated flower numbers.

Unassisted self-pollination was highly sporadic among populations and years. In Year 1 no seed set was obtained in four of the six populations, whereas in Year 2, small amounts of seed were obtained in five populations, exceptionally reaching 10\% in LP-high (Fig. 5). On average, over the two years only $1.1 \%$ and $3.6 \%$ respectively of the monitored flowers per population formed fruits in the unassisted selfpollination treatment. In general, it may be concluded that autonomous self-pollination is unimportant throughout the entire altitudinal range of $O$. compacta, deeming it highly dependent on external pollinators. 
TABLE III. Results of hand cross- and self-pollination, unassisted self-pollination and emasculation in Oxalis compacta subsp. compacta in the upper part of the high alpine belt, 3450 m,a.s.l., central Chile Andes. See Figure 3 for details on specific pollination combinations. Statistical comparisons are found in the text. See Fig.4 for details of crosses according to anther level employed in each cross-category.

TABLA III. Resultados de polinización cruzada manual, autopolinización manual, autopolinización no asistida y emasculación en Oxalis compacta subsp. compacta en la zona andina superior, $3.450 \mathrm{~m} \mathrm{s.m}$. Andes de Chile central. Ver Figura 3 para mayores detalles de las polinizaciones. Las comparaciones estadísticas se encuentran en el texto. Ver Fig. 4 para detalles de los cruces según nivel de antera usado en cada categoría de cruce.

\begin{tabular}{|c|c|c|c|c|}
\hline TREatment & $\begin{array}{l}\text { RECIPIENT } \\
\text { OVULATE PARENT }\end{array}$ & $\mathrm{N}$ & $\begin{array}{l}\text { PERCENT } \\
\text { FRUIT SET }\end{array}$ & $\begin{array}{c}\text { SEED/FLOWER POLLINATED } \\
\text { MEAN } \pm \mathrm{SE}\end{array}$ \\
\hline \multirow{4}{*}{$\begin{array}{l}\text { Legitimate } \\
\text { intermorph }\end{array}$} & L-morph & 16 & 68.8 & $3.31 \pm 0.75$ \\
\hline & M-morph & 14 & 78.6 & $4.00 \pm 0.74$ \\
\hline & S-morph & 6 & 50.0 & $1.67 \pm 0.99$ \\
\hline & All morphs & 36 & 69.4 & $3.31 \pm 0.48$ \\
\hline Illegitimate & L-morph & 16 & 43,8 & $2.06 \pm 0.76$ \\
\hline \multirow[t]{3}{*}{ intermorph } & M-morph & 14 & 21.4 & $0.57 \pm 0.43$ \\
\hline & S-morph & 6 & 50.0 & $1.33 \pm 0.61$ \\
\hline & All morphs & 36 & 36.1 & $1.36 \pm 0.40$ \\
\hline Illegitimate & L-morph & 16 & 37.5 & $1.69 \pm 0.71$ \\
\hline \multirow[t]{3}{*}{ intramorph } & M-morph & 14 & 26.6 & $1.29 \pm 0.59$ \\
\hline & S-morph & 6 & 33.3 & $0.33 \pm 0.21$ \\
\hline & All morphs & 36 & 33.3 & $1.31 \pm 0.39$ \\
\hline Hand & L-morph & 16 & 0 & 0 \\
\hline \multirow[t]{3}{*}{ self-pollination } & M-morph & 14 & 0 & 0 \\
\hline & S-morph & 6 & 0 & 0 \\
\hline & All morphs & 36 & $\mathbf{0}$ & $\mathbf{0}$ \\
\hline Unassisted & L-morph & 8 & 0 & 0 \\
\hline \multirow[t]{3}{*}{ self-pollinated } & M-morph & 7 & 0 & 0 \\
\hline & S-morph & 3 & 0 & 0 \\
\hline & All morphs & 18 & $\mathbf{0}$ & $\mathbf{0}$ \\
\hline Emasculated & L-morph & 8 & 0 & 0 \\
\hline \multirow[t]{3}{*}{ Untreated } & M-morph & 7 & 0 & 0 \\
\hline & S-morph & 3 & 0 & 0 \\
\hline & All morphs & 18 & $\mathbf{0}$ & $\mathbf{0}$ \\
\hline
\end{tabular}

Open-pollination fruit set varied from a low of $9.4 \%$ (LP-low, Year 1) to a high of $83.1 \%$ (VN-high, Year 2) and was more variable among years in the higher-elevation populations (Fig. 5). In Year 1 open-pollination fruit set was consistently lower in the three higher-elevation populations. In Year-2, fruit set turned out to be higher in the three upper-elevation populations. Considering the data for each population and year separately, the relative proportions of L- M- and S morph flowers producing fruits were always similar (based on 12 non-significant values of the G-test of Homogeneity). 

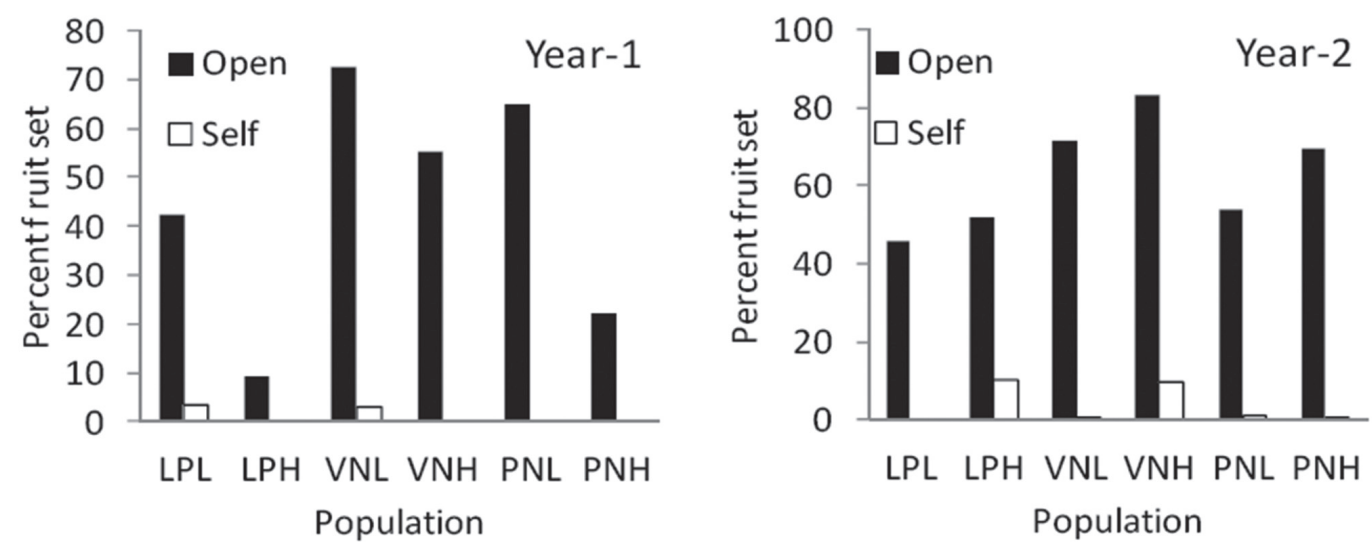

FigURE 5. Unassisted self-pollination fruit set and open-pollination fruit set in three high and three low populations of Oxalis compacta subsp. compacta in the upper alpine in the central Chilean Andes over the austral summers of 2008-2009 (Year -1) and 2009-2010 (Year-2). See Methods section for sample sizes.

Figura 5. Producción de frutos mediante autopolinización no asistida y polinización abierta en tres poblaciones altas y tres poblaciones bajas de Oxalis compacta subsp. compacta en la zona alpina superior en los Andes de Chile central en los veranos australes de 2008-2009 (Año-1) y 2009-2010 (Año-2). Ver sección de Metodología para los tamaños muestreales.

\section{DISCUSSION}

Detailed floral measurements confirmed that $O$. compacta has a high degree of reciprocity among anther and stigma heights, and thus conforms to a typical tristylous species from the point of view of its floral morphology. However, in one of the highest-elevation areas it occupies in the central Chilean Andes, its self-incompatibility system was seen to deviate in relation to strict heteromorphic incompatibility. All three morphs are capable of producing some seed under illegitimate inter-morph cross-pollination and illegitimate intramorph cross-pollination, in relation to that expected with typical heteromorphic incompatibility, although this is never as high as with legitimate intermorph cross pollination. The situation found in $O$. compacta contrasts strongly with that reported in $O$. squamata where illegitimate cross pollination seed set is absent or negligible (Marco \& Arroyo 1998). This second species of section Alpinae grows below 3000 m.a.s.l. on our study sites. Incompatibility expression as seen in $O$. compacta has been reported for many populations of $O$. alpina in North America (Weller et al. 2007). This particular species occurs in lower vegetation belts than our species.

While a considerable amount of illegitimate crosspollination is possible in $O$. compacta, the level of unassisted self-pollination was found to be low and sporadic. Indeed, autonomous selfing is likely to be even lower than we report. Our unassisted-pollination fruit set data were obtained in conjunction with observations on potential flower longevity under pollinator free conditions (flower longevity results to be published elsewhere). In order to record flower opening and closure, we were obliged to open the pollination exclosures briefly, always guarding the flowers against any incoming pollinators so as to comply with the required experimental protocol. However, occasional contamination by minute and exceedingly fast-flying Andrenid bees that escaped our control cannot be entirely ruled out, in which case the already low levels of autonomous selfing reported are possibly even lower. Consequently, it can be safely concluded that autonomous self-pollination is not an important reproductive assurance mechanism in $O$. compacta in the central Chilean Andes. A similar situation has also been reported in tristylous $O$. patagonica and $O$. loricata of section Palmatifolia in the Patagonian alpine (Arroyo \& Squeo 1990).

Among the seven populations of $O$. compacta studied for style morph frequencies, both isoplethic and anisoplethic populations were found. Morph ratios in tristylous species are governed by frequency-dependent selection and disassortative mating, together leading to equal morph frequencies (isoplethy) in a population at equilibrium (Heuch 1979). Anisoplethy (1) may represent a transient condition in a population evolving towards equilibrium or (2) result from inherent fitness differences among morphs (Ågren \& Ericson 1996). It can also (3) derive from modifications in the fertilization ability of pollen from the two whorls of anthers (Weller et al. 2007). Significantly we found no female fitness differences among the style morphs of $O$. compacta. Moreover the populations studied were large 
and presumably well established. Thus the first two causes are unlikely to explain the observed anisoplethic morph frequencies recorded in some populations.

With respect to the fertilization ability of pollen from the two anther whorls (3), Weller et al. (2007) pointed out that when pollen from both anther whorls of the L- and Smorphs is able to engage in the fertilization of the L- and $\mathrm{S}$-stigmas, respectively, an expected result is a depression in the frequency of the M-morph. Such a tendency in pollen fertilization ability was found in the experimental population of $O$. compacta, which also turned out to be M-deficient, suggesting that the cause of anisoplethy in $O$. compacta may effectively lie here. The presence of both anisoplethic and isoplethic populations in O. compacta on our study sites could indicate between-population variation in the expression of hetermorphic incompatibility in our species, as has been documented following more than 20 years of experimental work in the well studied North American tristylous Oxalis alpina (Weller 1979, Weller et al. 2007).

The copious body of research on heterostyly has devoted little attention to how, and/or the selective regimes under which alterations in heteromorphic incompatibility, such as that documented here in Oxalis compacta, arise. Illegitimate intramorph cross-pollination in particular potentially allows additional seed set over that expected in a tristylous species with strict heteromorphic incompatibility with no increase in pollinator visitation. This follows from the fact that all pollinator movements between plants of the same stylar morph in a typical tristylous species characterized by strong heteromorphic incompatibility fail in terms seed production. For an increase in legitimate intramorph seed set to occur without additional pollinator service, however, pollen reception and deposition must be dissassortative. Many heterostylous species have been reported to have imperfect dissassortative pollen deposition (Ganders 1979), and this seems highly likely to be the case in $O$. compacta. Among its principal pollinators, the tiny Andrenid bees shuffle around in the flowers in search of pollen such that all parts of their bodies become covered with pollen, with non-specific pollen deposition to be expected in the next visited flower. At high altitudes, where cold and unpredictable weather conditions and strong microclimatic differences related to slope-aspect and substrate type can have huge effects on flower visitation rates (Totland 1994, Bergman et al. 1996, Rozzi et al. 1997, TorresDíaz et al. 2007) and flower visitation rates vary widely over the season (Arroyo et al. 1985, Lundemo \& Totland 2007) and among years (e.g. Pérez et al. 2009), an increase in seed set due to a combination of altered incompatibility expression and non-disassortative pollen flow could have high selective value. Pérez-Barrales et al. (2006) have provided evidence that pollinators can exert important effects on the evolution and maintenance of floral polymorphisms such as heterostyly and on the change from tristyly to distyly.

The inversion in the fruit set tendency over the two years over the altitudinal gradient may be explained by differences in temperature conditions. In the first year, the flowers in each low and high population in a given area were marked over the exact same days. Thus climatic conditions, as they affect pollinator behavior over the altitudinal gradient were comparable. In that year, temperatures in the high elevation populations were 2-3 degrees lower than in the lower elevation populations (Arroyo, unpublished data). In Year 2 , the larger plant and flower sample sizes monitored forced us to study the six populations on different dates over the flowering season. The three low-elevation populations was studied either very early or very late in the summer season (when temperatures are cooler) in relation to their highelevation counterparts which were studied in mid-summer. In Year-2, in contrast to Year 1, temperatures were around 3$5^{\circ} \mathrm{C}$ higher in the upper-elevation populations in comparison with their low elevation counterparts (Arroyo, unpublished data), thus determining better pollination conditions in the higher elevation populations that particular year. Despite these nuances, the overall open-pollination fruit set trend, considering the mean for the two years, was for lower fruit set in the higher-elevation populations (mean of 30.7, 69.2 and $45.9 \%$ for the three upper-elevation compared with $43.9,71.9,59.5 \%$ for the three lower-elevation populations, respectively).

The selective value of intramorph illegitimate seed set should be particularly high in a tristylous species that is pollen-limited. The open-pollination fruit results in $O$. compacta revealed high inter-annual variation in fruit set levels, with lower fruits set levels in Year 1, suggesting the possibility of pollen limitation. Preliminary evidence for pollen limitation is available for two of the populations studied in that particular year. In Year 1, we had reason to hand-pollinate bagged L-morph flowers of $O$. compacta flowers in LP-high and PN-high in relation to other work (M.T. K. Arroyo, unpublished data), with a $>85 \%$ fruiting success rate in both populations. Open-pollination fruit set as reported in this paper for these same two populations was $9 \%$ and $22 \%$, respectively. Using the controlled hand-pollinated data as a bench mark for physiologically-maximum fruit set leads to estimates of between 74-89\% pollen limitation in LP-high and PN-high in this particular year. Nevertheless, the higher fruit sets obtained in Year 2 (52.0\%, LP-high; 69.1\%, PN-high), when compared with the same benchmark figure, indicates little pollen limitation the following year. Pérez et al. (2009) showed that the evolution of reproductive assurance in Schizanthus grahamii is associated with inter-annual fluctuation in pollinator availability. We hypothesize that the imperfect expression of heteromorphic incompatibility seen in $O$. compacta, where considerable seed set is possible via illegitimate pollination, has evolved or has been selected for by the ecological sorting of lineages with these particular characteristics, to increase effectiveness in use of the pollinator resource in years, or at times of the year when the latter is 
less abundant. Arroyo et al. $(1985,2006)$ proposed that alpine species may acquire compensatory traits which increase the probability that a flower is pollinated when pollination service is depressed or temporally and spatially fluctuating, thereby enabling the maintenance of outcrossing breeding systems and high seed set levels (increased pollination probability hypothesis). In accordance with this general notion, our experimental demonstration of the possibility of illegitimate seed set in $O$. compacta combined with lack of autonomous self-pollination can be seen as novel compensatory mechanism for increasing seed set in the high alpine as per the increased pollination probability hypothesis.

In conclusion, tristylous $O$. compacta exhibits a modified form of incompatibility expression in which capacity for seed set following illegitimate intramorph pollination in particular has the potential to increase the effectiveness of pollinator visits in the upper alpine, without loss of genetic variability and attendant inbreeding. Additional crossing work on more populations and more extensive studies on pollen limitation are highly desirable in $O$. compacta in order to determine whether incompatibility expression as documented here is characteristic of its entire geographical distribution. Detailed studies on floral display and its effects on pollen carryover would also be desirable to further knowledge of the evolutionary factors that underlie the $O$. compacta breeding system. With its generally low and sporadic unassisted selfing capacity in the central Chilean Andes, tristylous $O$. compacta joins the growing list of alpine plants that are strongly adapted for outcrossing (e.g. Pojar 1974, Arroyo \& Squeo 1990, Galen et al. 1991, Stenström \& Molau 1992, Ægisdóttir et al. 2007, Ladd \& Arroyo 2009, Pérez et al. 2009, Wirth et al. 2010).

\section{ACKNOWLEDGEMENTS}

Work was funded by Fondecyt-Chile 1085013, Contracts ICM P005-02 and Conicyt PFB-23. We are grateful to Diego Pacheco, Paulina Aguilera, Nicolás Parada, Gianina Romero, Karen Ruiz and Pablo Céspedes for their assistance in the field. Daniela Domínguez held an IEB (Chile) Masters fellowship and Gus Jespersen an NSF (USA) IGERT fellowship during the tenure of the field work. Special thanks are extended to the La Parva and Valle Nevado Ski companies for permission to work on their properties.

\section{LITERATURE CITED}

ABID, R. 2010. Floral morphs and mode of pollination in Oxalis corniculata L., from Pakistan. Pakistan Journal of Botany 42: 4027-4033.

Ægisdóttir, H.H., D. Jespersen, P. Kuss \& J. Stöcklin. 2007. No inbreeding depression in an outcrossing alpine species:
The breeding system of Campanula thyrsoides. Flora Morphology, Distribution, Functional Ecology of Plants 202: $218-225$.

Ågren, J. \& L. Ericson. 1996. Population structure and morphspecific fitness differences in tristylous Lythrum salicaria. Evolution 50: 126-139.

Arroyo, M.T.K., R.B. Primack \& J.J. Armesto . 1982. Community studies in pollination ecology in the high temperate Andes of central Chile I. Pollination mechanisms and altitudinal variation. American Journal of Botany 69: 82-97.

Arroyo, M.T.K., J.J. Armesto \& R.B. Primack. 1985. Community studies in pollination ecology in the high temperate Andes of central Chile II. Effect of temperature on visitation rates and pollination possibilities. Plant Systematics and Evolution 149: 187-203.

Arroyo, M.T.K. \& F.A. SQueo. 1990. Relationships between plant breeding systems and pollination. In: S. Kawano S (ed.), Biological approaches and evolutionary trends in plants, pp. 205-227. Academic Press, San Diego.

Arroyo, M.T.K., M.S. Muñoz, C. Henríquez, I. Till-Bottraud \& F. PÉREZ. 2006. Erratic pollination, high selfing levels and their correlates and consequences in an altitudinally widespread above tree-line species in the high Andes of Chile. Acta Oecologica 30: 248-257.

Arroyo, M.T.K., LE. Dudley, P. Pliscoff, LA. Cavieres, F.A. Squeo, C. Marticorena \& R. Rozzi. 2010. A possible correlation between the altitudinal and latitudinal ranges of species in the high elevation flora of the Andes. In: E.M. Spehn \& C. Körner (eds.), Data Mining for Global Trends in Mountain Biodiversity, pp. 39-47. CRC Press, Taylor and Francis, Boca Raton.

BARRETT, S.C.H. 1992. Evolution and function of heterostyly. Springer-Verlag, Berlin.

Barrett, S.C.H., L.K. Jesson \& A.M. BAKer. 2000. The evolution and function of stylar polymorphisms in flowering plants. Annals of Botany 85: 253-265.

Barrett, S.C.H. \& J.S. Shore. 2008. New insights on heterostyly: Comparative biology, ecology and genetics. In: V. Franklin-Tong (ed.), Self-Incompatibility in Flowering Plants: Evolution, Diversity and Mechanisms, pp. 3-32. Springer-Verlag, Berlin.

Bergman, P., U. Molau \& B. Holmgren. 1996. Micrometeorological impacts of insect activity and plant reproductive success in an alpine environment. Arctic and Alpine Research 28: 196-202.

Castro, S., J. Loureiro, C. Santos, M. Ater, G. Ayensa \& L. NAVARRo. 2007. Distribution of flower morphs, ploidy level and sexual reproduction of the invasive weed Oxalis pescaprae in the western area of the Mediterranean region. Annals of Botany 99: 507-517.

DARWIN, C.R. 1877. The different forms of flowers on plants of the same species. John Murray, London. 352 pp.

DomíngueZ, D. 2010. Detección de rasgos que compensarían la disminución altitudinal del servicio de polinización comunitaria en una especie heterostílica en la Cordillera de los Andes de Chile central. Masters Dissertation, Universidad de Chile, Chile. 70 pp.

FyFe, V.C. 1950. The genetics of tristyly in Oxalis valdiviensis. Heredity 4: 365-371.

Galen, C., J.S. Shore \& H. Deyoe. 1991. Ecotypic divergence in alpine Polemonium viscosum: genetic structure, quantitative variation, and local adaptation. Evolution 45: 
$1218-1228$

Ganders, F. 1979. The biology of heterostyly. New Zealand Journal of Botany 17: 607-635.

García-Camacho, R. \& Ø. Totland. 2009. Pollen limitation in the alpine: A meta-analysis. Arctic, Antarctic, and Alpine Research 41: 103-111.

Heuch, I. 1979. Equilibrium populations of heterostylous plants. Theoretical Population Biology 15: 43-57.

Hussey, B., G. Keighery, R. Cousens, J. Dodd \& S. Lloyd. 1997. Western weeds - a guide to the weeds of Western Australia. The Plant Protection Society of Western Australia, Victoria Park. 294 pp.

Kalisz, S. \& D.W. Vogler. 2003. Benefits of autonomous selfing under unpredictable pollinator environments. Ecology 84: 2928-2942.

LadD, P.G. \& M.T.K. Arroyo. 2009. Comparisons of breeding systems between two sympatric species, Nastanthus spathulatus (Calyceraceae) and Rhodophiala rhodolirion (Amaryllidaceae), in the high Andes of central Chile. Plant Species Biology 24: 2-10.

Lourteig, A. 2000. Oxalis L. Subgéneros Monoxalis (Small) Lourt., Oxalis y Trifidus Lourt. Bradea 7: 201-629.

Lundemo, S. \& Ø. TotLAND 2007. Within-population spatial variation in pollinator visitation rates, pollen limitation on seed set, and flower longevity in an alpine species. Acta Oecologica 32: 262-268.

Luo, S., D. Zhang \& S.S. Renner. 2006. Oxalis debilis in China: Distribution of flower morphs, sterile pollen and polyploidy. Annals of Botany 98: 459-464.

Marco, D.E. \& M.T.K. Arroyo. 1998. The breeding system of Oxalis squamata, a tristylous South American species. Botanica Acta (Germany) 111: 497-504.

Muñoz, A.A. \& M.T.K. Arroyo. 2006. Pollen limitation and spatial variation of reproductive success in the insectpollinated shrub Chuquiraga oppositifolia (Asteraceae) in the Chilean Andes. Arctic, Antarctic, and Alpine Research 38: 608-613.

ORnDUFF, R. 1964. The breeding system of Oxalis suksdorfii. American Journal of Botany 51: 307-314.

ORNDUFF, R. 1972. The breakdown of trimorphic incompatibility in Oxalis section Corniculatae. Evolution 26: 52-65.

Pacques de Barro Pacheco, R. \& J.R. Coleman. 1989. Reproductive morphology, genetic control and incompatibility relationships in tristylous Oxalis physocalyx (Oxalidaceae). Brazilian Journal of Genetics 12: 347-359.

Pérez-Barrales, R., P. Vargas \& J. Arroyo. 2006. New evidence for the Darwinian hypothesis of heterostyly: Breeding systems and pollinators in Narcissus sect. Apodanthi. New Phytologist 171: 553-567.

Pérez, F., M.T.K. Arroyo \& J.J. Armesto. 2009. Evolution of autonomous selfing accompanies increased specialization in the pollination system of Schizanthus (Solanaceae). American Journal of Botany 96: 1168-1176.

PoJAR, J. 1974. Reproductive dynamics of four plants communities of southwestern British Colombia. Canadian Journal of Botany 52: 1819-1834

Richards, J.H. \& S. Koptur S. 1993. Floral variation and distyly in Guettarda scabra (Rubiaceae). American Journal of Botany 80: 31-40.

Rozzi, R., M.T.K. Arroyo \& J.J. Armesto. 1997. Ecological factors affecting gene flow between populations of Anarthrophyllum cumingii (Papilionaceae) growing on equatorial and polar-facing slopes in the Andes of Central Chile. Plant Ecology 132: 171-179.

Stenström, M. \& U. Molau. 1992. Reproductive ecology of Saxifraga oppositifolia: phenology, mating system and reproductive success. Arctic and Alpine Research 24: 337343.

Torres-Díaz, C., L.A. Cavieres, C. Muñoz-Ramírez \& M.T.K. Arroyo. 2007. Consecuencias de las variaciones microclimáticas sobre la visita de insectos polinizadores en dos especies de Chaetanthera (Asteraceae) en los Andes de Chile central. Revista Chilena de Historia Natural 80: 455-468.

Totland, Ø. 1994. Influence of climate, time of day and season, and flower density on insect flower visitation in Alpine Norway. Arctic and Alpine Research 26: 66-71

WELLER, S.G. 1976. The genetic control of tristyly in Oxalis section Ionoxalis. Heredity 37: 387-393.

WeLLER, S.G. 1979. Variation in heterostylous reproductive systems among populations of Oxalis alpina in southeastern Arizona. Systematic Botany 4: 57-71.

WELLER, S.G. 1980. The incompatibility relationships of tristylous Oxalis section Inoxalis of southern Mexico. Canadian Journal of Botany 58: 1908-1911.

Weller, S.G., C.A. Domínguez, F.E. Molina-Freaner, J. Fornoni \& G. LeBuhn. 2007. The evolution of distyly from tristyly in populations of Oxalis alpina (Oxalidaceae) in the Sky Islands of the Sonoran Desert. American Journal of Botany 94: 972-985.

Wirth, L.R., R. Graf, F. Gugerli, U. Landergott \& R. HolderegGer. 2010. Lower selfing rate at higher altitudes in the alpine plant Eritrichium nanum (Boraginaceae). American Journal of Botany 97: 899-901.

WyatT, R. 1983. Pollinator-plant interactions and the evolution of breeding systems. In: L. Real (ed.), Pollination biology, pp. 51-95. Academic Press, London.

Zietsman, J., K.K. Dreyer \& K.J. EsLer. 2008. Reproductive biology of selected rare and endangered Oxalis L. (Oxalidaceae) plant species. Biological Conservation 141: 1475-1483.

Recibido: 25.10.11

Aceptado: 30.03 .12 